\title{
Expression of nitric oxide synthase in macula densa in streptozotocin diabetic rats
}

\author{
N. Yagihashi ${ }^{1}$, N. Nishida ${ }^{1}$, H. Geuk Seo ${ }^{2}$, N. Taniguchi ${ }^{2}$, S. Yagihashi ${ }^{1}$ \\ ${ }^{1}$ Department of Pathology, Hirosaki University School of Medicine, Hirosaki, Japan \\ ${ }^{2}$ Department of Biochemistry, Osaka University School of Medicine, Osaka, Japan
}

\begin{abstract}
Summary Renal haemodynamic changes are suggested to be an early sign of diabetic glomerulopathy. The juxtaglomerular apparatus relevant to the reninangiotensin system, known to be the site of nitric oxide (NO) production, is considered to play a role in the regulation of glomerular blood flow. This study was therefore designed to clarify whether in situ expression of nitric oxide synthase (NOS) is altered in the kidney of diabetic rats. Streptozotocin-induced diabetic rats with $6,8,12$ and 32 weeks' diabetes duration and age-matched normal control rats were used. The expression of a constitutive form of NOS (cNOS, neural type) and NADPH diaphorase activity in the renal cortex were studied immunohistochemically and histochemically. Diabetic rats had lower body weight and heavier kidney mass compared to control rats at each time point examined. Mean glomerular surface area was greater in 6,8 and 12 -week diabetic rats compared to age-matched control rats. cNOS reaction was localized in the macula densa and appeared less intense in diabetic rats compared
\end{abstract}

to age-matched control rats. The mean number of macula densa cells positive for cNOS in each glomerulus and in each glomerular area was significantly lower in diabetic rats compared to control rats at any time examined. In contrast, NADPH diaphorase activity was detected in both juxtaglomerular arterioles and macula densa cells. The staining reaction of NADPH diaphorase in the arterioles remained positive but appeared less intense in macula densa cells in diabetic rats. These results suggest that NO production in macula densa cells may be reduced in diabetic rats, modulating the vasodilatory function of afferent arterioles. Further investigation on the changes in inducible NOS as well as endothelial cNOS are necessary to clarify mechanisms of haemodynamic changes in the diabetic kidney. [Diabetologia (1996) 39: 793-799]

Keywords Diabetes mellitus, glomerulopathy, cNOS (neural type), macula densa, morphometry, NADPH diaphorase, immunocytochemistry.
Increased kidney size with glomerular hyperfiltration has been found to be an early sign of diabetic nephropathy in human diabetic patients [1-3]. These renal abnormalities have also been demonstrated in experimentally induced diabetic animal models, in which mechanisms of these abnormalities have been explored $[4,5]$. In the regulation of glomerular blood

Received: 27 September 1995 and in final revised form: 13 February 1996

Corresponding author: Dr. S. Yagihashi, Department of $\mathrm{Pa}-$ thology, Hirosaki University School of Medicine, 5 Zaifu-cho, Hirosaki 036, Japan flow, the juxtaglomerular apparatus (JGA) has been suggested to play a major role $[6,7]$. Altered activity of the renin angiotensin system [8,9], impaired expression of angiotensin-II receptors in afferent arterioles [10], and enhanced expression of endothelin with reduced renin release from JGA [11] are suggested to be responsible for the glomerular hyperfiltration in diabetes. Recent studies have also proposed a role for atrial natriuretic peptide (ANP) [12] and its receptors [13] in the early alterations of glomerular haemodynamics in diabetic rats. Tubuloglomerular feedback through the macula densa cells is known to play a central role in these altered haemodynamics $[6,14,15]$. One study has shown that macula densa 
cells directly inhibit renin secretion from afferent arterioles [16].

Recent experimental studies have shown that endothelium-derived relaxing factor or nitric oxide (NO) also participates in the regulation of renal blood flow and its changes in the diabetic state [1719]. Histological studies using immunohistochemistry and in situ hybridization detected localization of neural constitutive NOS (cNOS) in macula densa cells [20-24]. NO produced by macula densa cells or afferent arterioles is considered to regulate glomerular filtration by inhibiting renin secretion $[20,25]$. It is not known, however, whether the alteration of cNOS expression in macula densa cells occurs in diabetic rats.

In the present study, we examined cNOS and NADPH diaphorase activity immunohistochemically and histochemically, respectively in the kidneys of rats after various durations of diabetes using quantitative analysis.

\section{Materials and methods}

Animals. Male Wistar rats 8 weeks of age were made diabetic by injection of $45 \mathrm{mg} / \mathrm{kg}$ i.v. streptozotocin (STZ; Sigma Chemical Co., St. Louis, Mo., USA) dissolved in $0.1 \mathrm{~mol} / 1 \mathrm{citric}$ buffer ( $\mathrm{pH} 4.2)$. One week after STZ injection, 20 diabetic rats (blood glucose levels $>19.3 \mathrm{mmol} / \mathrm{l}$ ) were randomly divided into four groups and followed for up to $6,8,12$, and 32 weeks. At each point 5 age-matched normal control rats were used for comparison. At the end of the study, all the animals were anaesthetized with an overdose of i.p. sodium pentobarbital (Abbott Ltd., Chicago, Ill., USA), and body weight and blood glucose levels were measured. Thereafter, the left kidney was extirpated from each rat and weighed. Two 1-mm thick slices cut horizontally from the central portion of the kidney were fixed in acetone overnight at $-20^{\circ} \mathrm{C}$ followed by paraffin embedding based on the AMeX method to preserve the antigens [26]. Horizontal duplicate paraffin sections were used for general light microscopic observations after staining with haematoxylin and eosin and for immunostaining and histochemical staining. Blood glucose levels were determined with a glucose reflectance dextrometer (Toecho-super; Kyoto Daiichi-Kagaku, Kyoto, Japan).

cNOS immunostaining. For the immunohistochemical detection of cNOS, we used the streptavidin biotin complex method (Histofine SAB-PO Kit; Nichirei Co., Tokyo, Japan). Ten-micron thick horizontally cut deparaffinized sections obtained from the central portion of the kidney were incubated with primary antiserum against cNOS (polyclonal rabbit antiserum to rat neural type NOS, diluted $1: 1500$ ) [27] overnight at $4^{\circ} \mathrm{C}$. After being rinsed in phosphate buffered saline (PBS), sequential incubations in secondary biotinylated goat anti-rabbit IgG antibody for $20 \mathrm{~min}$ and peroxidase conjugated streptavidin for $10 \mathrm{~min}$ followed at room temperature, interspersed with washes in PBS. 3, 3'-Diaminobenzidine tetrahydrochloride was used as chromogen. The sections were then counterstained with methyl green. Specificity of immunostaining was verified by replacing the primary antibody with PBS. The sections of diabetic and age-matched control rats at a given point were placed on the same slide, and immunostaining was performed under constant conditions for comparison of distribution and intensity of immunoreactions. Staining was performed on the two sections of different tissue blocks for each rat.

Morphometric analysis of cNOS positive cells. After immunohistochemical staining the total numbers of glomeruli were counted on two cut sections of total renal cortical areas at a magnification of $\times 80$ and glomerular density (number of glomeruli per unit cortical area) was represented in each rat. Mean glomerular surface area (GSA) was obtained from the measurement of at least 100 glomeruli on each section at a magnification of $\times 200$. GSA was delineated by the inner circumference of the Bowman's capsule. The number of cNOS positive cells in macula densa cells was obtained by counting the number of nuclei of positive cells. For objective quantification, the number of cNOS-positive cells was expressed as the number of positive cells per single glomerulus or per unit GSA by dividing the total number of positive cells by total GSA or by number of glomeruli. For the measurement of surface areas, an NIH image analysis system connected to a personal computer (Macintosh Quadra 9100; Apple Japan Inc., Tokyo, Japan) was used. All morphometric analyses were performed in a double masked manner.

Immunoelectron microscopy. For immunoelectron microscopy, small pieces of renal cortical tissues of $1.5 \times 2 \times 2 \mathrm{~mm}^{3}$ were freshly removed from the upper portion of the left kidney of each rat 8 weeks after the onset of diabetes and from the agematched control rats. The samples were immediately fixed with periodate-lysine $4 \%$ paraformaldehyde overnight at $4^{\circ} \mathrm{C}$, and washed three times in PBS with increasing concentrations of sucrose $(10,15$, and $20 \%)$ for about $6 \mathrm{~h}$ each at $4^{\circ} \mathrm{C}$. The fixed specimens were then embedded in gelatinous O.C.T. compounds (Tissue-Tek; Miles Inc., Elkhart, In., USA), frozen quickly in liquid nitrogen, and sectioned (10 $\mu \mathrm{m}$ thick) on a cryostat microtome. The sections were placed on poly-L-lysine-coated glass slides and dried in air at room temperature. The sections were then immunostained in a similar manner as for the light microscopy but with longer incubation times with antibodies, they were washed and reacted with $2 \%$ osmium tetroxide, dehydrated in a graded series of ethanol, and embedded in epon. Ultrathin sections stained with lead citrate were examined on a JEOL TEM-2000 EX electron microscope (Nihon-densi, Tokyo, Japan).

NADPH diaphorase staining. For histochemical staining of NADPH diaphorase, $10-\mu \mathrm{m}$ thick deparaffinized sections were incubated with $0.1 \mathrm{~mol} / 1$ Tris- $\mathrm{HCl}$ buffer ( $\mathrm{pH} 7.6$ ) containing $1 \mathrm{mmol} / \mathrm{l}$ reduced $\beta$-NADPH (Sigma), $0.2 \mathrm{mmol} / \mathrm{l}$ nitro blue tetrazolium (WAKO Pure Chemicals Ltd., Osaka, Japan) and $0.2 \%$ Triton $\mathrm{X}-100$ for $30 \mathrm{~min}$ at $37^{\circ} \mathrm{C}$ [28]. The sections were then rinsed in $0.05 \mathrm{~mol} / 1$ Tris- $\mathrm{HCl}$ buffer and mounted on glass slides.

\section{Statistical analysis}

All values are expressed as mean \pm SD of five animals in each group. Comparison of the mean values between control and diabetic groups at each point was made by Student's $t$-test (two tailed) and multiple comparisons with time after the onset of diabetes were based on the ANOVA with post-hoc Bonferroni correction. $P$ values less than 0.05 were considered to be significant. 
Table 1. Body weights, blood glucose levels and kidney weights in the experimental rats

\begin{tabular}{|c|c|c|c|c|c|c|c|c|}
\hline \multirow[t]{2}{*}{ Diabetes duration } & \multicolumn{2}{|l|}{6 week } & \multicolumn{2}{|l|}{8 week } & \multicolumn{2}{|l|}{12 week } & \multicolumn{2}{|l|}{32 week } \\
\hline & Control & Diabetic & Control & Diabetic & Control & Diabetic & Control & Diabetic \\
\hline & 5 & 5 & 5 & 5 & 5 & 5 & 5 & 5 \\
\hline Body weight (g) & $342 \pm 28^{c}$ & $279 \pm 18^{\mathrm{a}}$ & $359 \pm 23^{\mathrm{d}}$ & $289 \pm 27^{\mathrm{a}}$ & $408 \pm 13$ & $294 \pm 15^{\mathrm{a}}$ & $504 \pm 51^{\mathrm{c}}$ & 265 \\
\hline Blood glucose $(\mathrm{mmol} / \mathrm{l})$ & $4.55 \pm 0.02$ & $25.57 \pm 2.70^{\mathrm{a}}$ & $5.01 \pm 0.67$ & $26.50 \pm 1.43^{\mathrm{a}}$ & $5.68 \pm 1.21$ & $26.11 \pm 3.14^{\mathrm{a}}$ & $5.84 \pm 0.83$ & $24.96 \pm 2.31^{a}$ \\
\hline Left kidney weight $(\mathrm{g})$ & $1.07 \pm 0.08$ & $1.57 \pm 0.10^{\mathrm{a}}$ & $1.08 \pm 0.08$ & $1.59 \pm 0.11^{\mathrm{a}}$ & $1.22 \pm 0.09^{\mathrm{e}}$ & $1.74 \pm 0.14^{\mathrm{a}}$ & $1.48 \pm 0.18^{\mathrm{f}}$ & $1.83 \pm 0.22^{\mathrm{h}, \mathrm{g}}$ \\
\hline
\end{tabular}

Values are means \pm SD. ${ }^{a} p<0.01$ control vs age-matched diabetic group; ${ }^{\mathrm{b}} p<0.05$ control vs age-matched diabetic group; ${ }^{\mathrm{c}} p<0.01$ vs 12 week control group; ${ }^{\mathrm{d}} p<0.05$ vs 12 week

control group; ${ }^{\mathrm{e}} p<0.01$ vs $6,8,12$ week control group; ${ }^{\mathrm{f}} p<0.01$ vs $6,8,12$ week control group; ${ }^{\mathrm{g}} p<0.05$ vs 6,8 week diabetic group

Table 2. Glomerular density and mean surface area in the experimental rats

\begin{tabular}{|c|c|c|c|c|c|c|c|c|}
\hline \multirow[t]{2}{*}{ Diabetes duration } & \multicolumn{2}{|l|}{6 week } & \multicolumn{2}{|l|}{8 week } & \multicolumn{2}{|l|}{12 week } & \multicolumn{2}{|l|}{32 week } \\
\hline & Control & Diabetic & Control & Diabetic & Control & Diabetic & Control & Diabetic \\
\hline Number of animals & 5 & 5 & 5 & 5 & 5 & 5 & 5 & 5 \\
\hline $\begin{array}{l}\text { Glomerular density } \\
\left(\# / \mathrm{mm}^{2}\right)\end{array}$ & $5.25 \pm 0.55$ & $3.96 \pm 0.57^{\mathrm{b}}$ & $5.00 \pm 0.33$ & $4.08 \pm 0.35^{\mathrm{a}}$ & $4.69 \pm 0.16^{c}$ & $4.13 \pm 0.27^{b}$ & $4.26 \pm 0.33^{\mathrm{d}}$ & $3.92 \pm 0.35$ \\
\hline $\begin{array}{l}\text { Glomerular surface } \\
\text { area }\left(\mu \mathrm{m}^{2}\right)\end{array}$ & $9542 \pm 1309$ & $11855 \pm 1197^{\mathrm{a}}$ & $11222 \pm 1311$ & $12782 \pm 1368^{b}$ & $11741 \pm 789^{\mathrm{e}}$ & $13750 \pm 780^{\mathrm{a}, \mathrm{f}}$ & $16160 \pm 1756^{\mathrm{g}}$ & $17142 \pm 1221^{\mathrm{h}}$ \\
\hline
\end{tabular}

Values are means \pm SD. ${ }^{a} p<0.01$ control vs age-matched diabetic group; ${ }^{b} p<0.05$ control vs age-matched diabetic group; ${ }^{\mathrm{c}} p<0.05$ vs 6 week control group; ${ }^{\mathrm{d}} p<0.01$ vs 6,8 week control group; ${ }^{\mathrm{e}} p<0.05$ vs 6 week control group; ${ }^{\mathrm{t}} p<0.05$ vs 6 week diabetic group; ${ }^{\mathrm{g}} p<0.01$ vs $6,8,12$ week control group;

${ }^{\text {h }} p<0.01$ vs $6,8,12$ week diabetic groups

Table 3. Population of cNOS positive cells in macula densa of the experimental rats

\begin{tabular}{|c|c|c|c|c|c|c|c|c|}
\hline \multirow[t]{2}{*}{ Diabetes duration } & \multicolumn{2}{|l|}{6 week } & \multicolumn{2}{|l|}{8 week } & \multicolumn{2}{|l|}{12 week } & \multicolumn{2}{|l|}{32 week } \\
\hline & Control & Diabetic & Control & Diabetic & Control & Diabetic & Control & Diabetic \\
\hline Number of animals & 5 & 5 & 5 & 5 & 5 & 5 & 5 & 5 \\
\hline $\begin{array}{l}\text { Number of NOS positive } \\
\text { cells per glomerulus }\end{array}$ & $2.52 \pm 0.22$ & $1.73 \pm 0.29^{\mathrm{a}}$ & $2.14 \pm 0.24^{b}$ & $1.29 \pm 0.12^{\mathrm{a}, \mathrm{c}}$ & $2.43 \pm 0.25$ & $1.54 \pm 0.37^{\mathrm{a}}$ & $1.61 \pm 0.27^{\mathrm{d}}$ & $0.70 \pm 0.20^{\text {a.e }}$ \\
\hline $\begin{array}{l}\text { Number of NOS positive } \\
\text { cells per glomerular } \\
\text { surface area }\left(\# / \mathrm{mm}^{2}\right)\end{array}$ & $269 \pm 53$ & $148 \pm 32^{\mathrm{a}}$ & $193 \pm 22^{f}$ & $102 \pm 15^{\text {a.g }}$ & $207 \pm 25^{\mathrm{h}}$ & $112 \pm 24^{\mathrm{a}}$ & $102 \pm 27^{i}$ & $41 \pm 16^{\mathrm{a} \cdot \mathrm{j}}$ \\
\hline
\end{tabular}

Values are means $\pm \mathrm{SD} .{ }^{a} p<0.01$ control vs age-matched diabetic group, ${ }^{\mathrm{b}} p<0.05$ vs 6 week control group; ${ }^{\mathrm{c}} p<0.05$ vs 6 week diabetic group; ${ }^{\mathrm{d}} p<0.01$ vs $6,8,12$ week control group; ${ }^{\mathrm{e}} p<0.0$ vs $6,8,12$ week diabetic group; ${ }^{\mathrm{f}} p<0.01$ vs 6 week control group; ${ }^{\mathrm{g}} p<0.01$ vs 6 week diabetic group; ${ }^{\mathrm{h}} p<0.05$ vs 6 week control group; ${ }^{i} p<0.01$ vs $6,8,12$ week control group; ${ }^{\mathrm{j}} p<0.01$ vs $6,8,12$ week diabetic group

\section{Results}

Body weights of STZ-induced diabetic rats were significantly lower than age-matched control rats at all times examined (Table 1). Diabetic rats showed higher blood glucose levels than normal controls, and heavier kidney weights. With increasing age, kidney weights of both control and diabetic rats were increased but the difference between control and diabetic rats became less significant. Mean glomerular density was decreased with age in normal control rats and was significantly lower in diabetic rats at 6,8 , and 12 weeks, but not at 32 weeks, compared with non-diabetic control rats (Table 2). Mean GSA was increased with age and was greater in diabetic rats than in control rats at 6,8 and 12 weeks, but not at 32 weeks.

Immunohistochemical staining of cNOS showed a positive reaction exclusively of the macula densa cells in the JGA in both diabetic and age-matched normal control rats (Fig. 1). Cellular components of the glomerulus and endothelial and smooth muscle cells of afferent and efferent arterioles were all negative. Immunoreactions appeared to be less intense in diabetic rats when compared to age-matched normal control rats at each point after the onset of diabetes.

Morphometrically, the number of cNOS positive cells per GSA or per single glomerulus was significantly lower in diabetic rats compared to age-matched normal control rats at any point examined (Table 3). At 32 weeks both diabetic and normal control rats showed reductions in cNOS positive cells compared to younger rats.

Immunoelectron microscopy revealed that cNOS was localized to macula densa cells and epithelial cells of the Bowman's capsule. Electron dense deposits were observed within the cytoplasm and no 

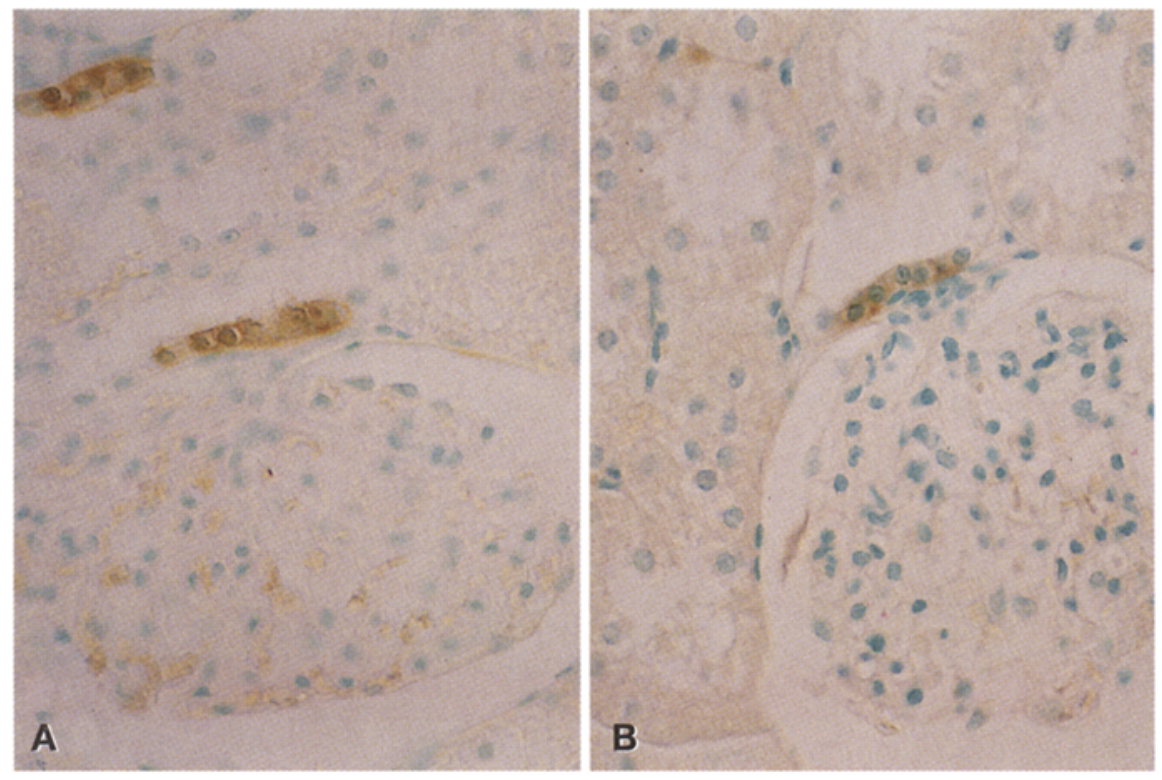

Fig. 1A, B. Immunohistochemical staining of neural constitutive form of nitric oxide synthase (cNOS) on the renal sections. Positive reactions are localized to the macula densa cells and staining intensity appears weaker in the diabetic rat (B, 8 weeks diabetes) as compared to an age-matched normal control rat (A). $\times 200$

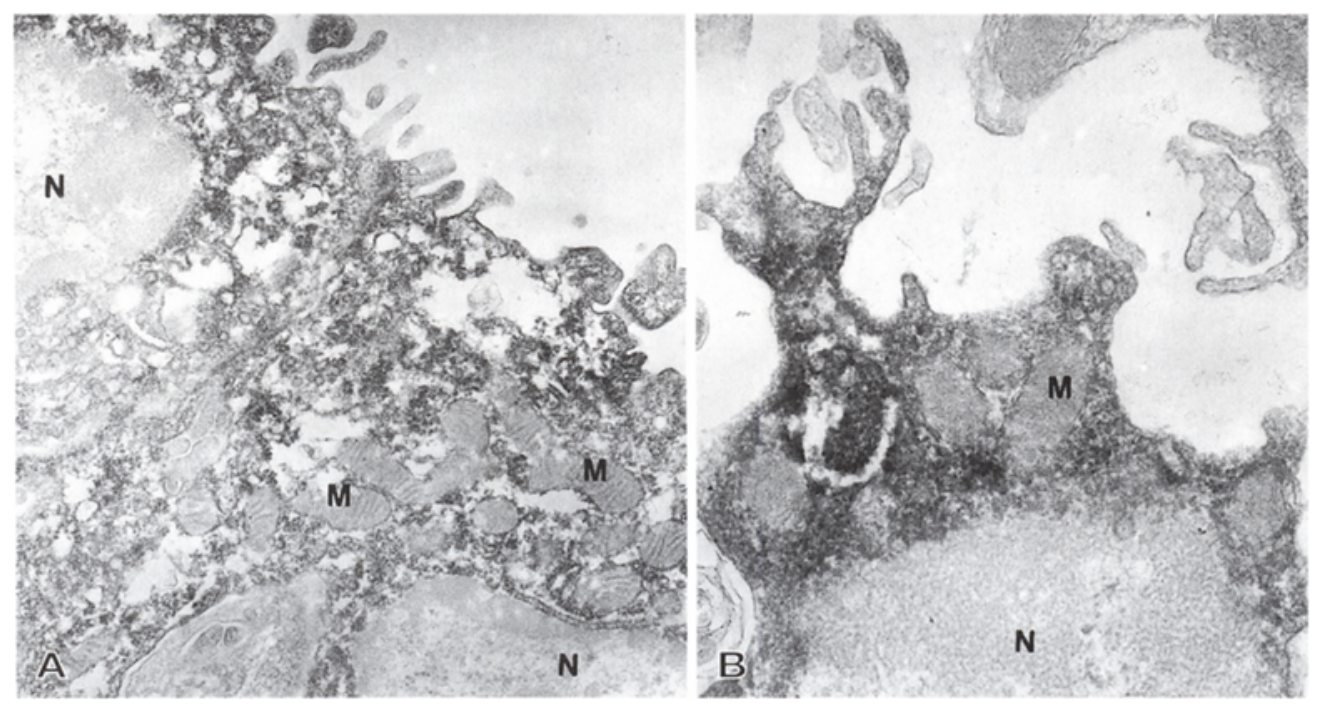

Fig. 2 A, B. Immunoelectron microscopic appearance of neural cNOS reactions in the macula densa cells. Positive reactions are found in the cytoplasm, but not in membranous structures or nuclei, in both diabetic $(A, \times 12000)$ and control rats $(B, \times 20000)$. $\mathrm{M}$, mitochondria; $\mathrm{N}$, nucleus
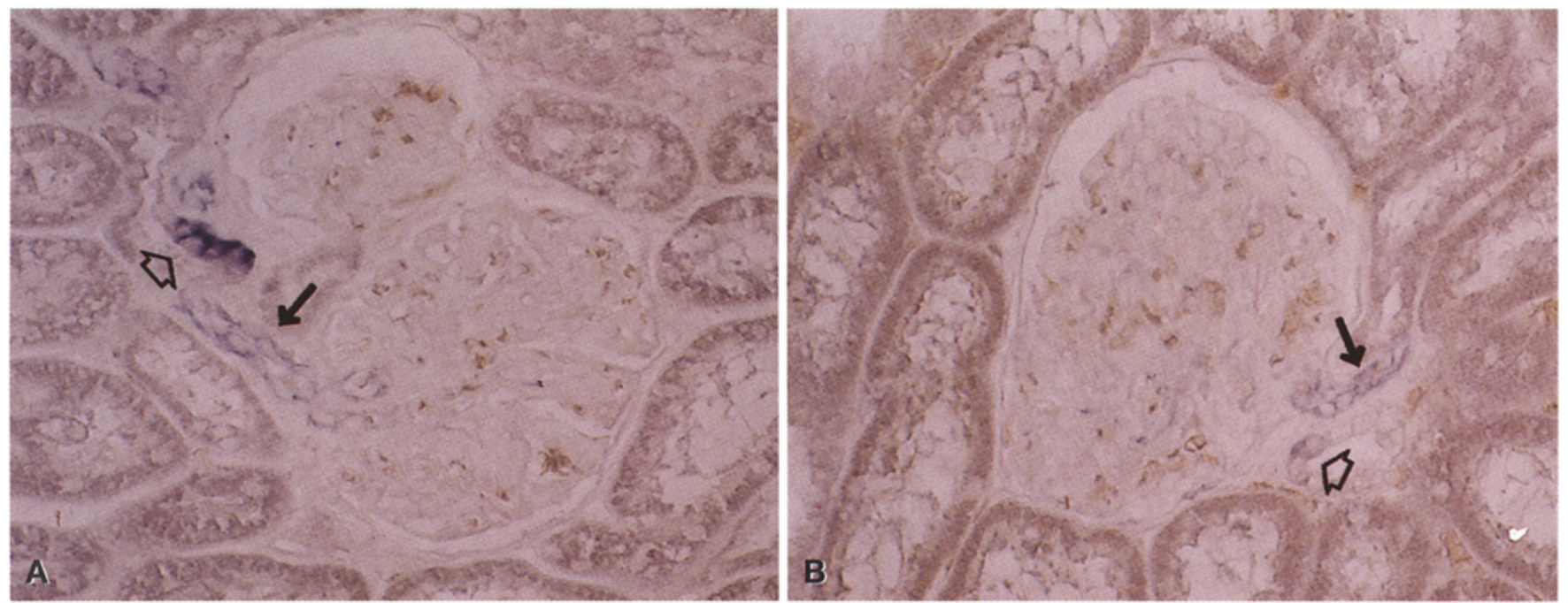

Fig. $3 \mathbf{A}, \mathbf{B}$. NADPH diaphorase activity in the renal sections. The positive reaction is localized in the macula densa cells (open arrow) and afferent arterioles (closed arrow) in a normal control rat $(\mathrm{A})$, whereas the staining reaction is weak in

macula densa cells (open arrow) but remained positive in afferent arteriole (closed arrow) in a diabetic rat (B, 8 weeks' diabetes). $\times 200$ 
association with the plasma membrane and the cytoplasmic vesicles was seen (Fig. 2). At the electron microscopic level, there was no apparent difference in staining intensity between diabetic and normal control rats.

NADPH diaphorase staining showed a clear positive reaction in macula densa cells and arteriolar walls in the JGA in normal control rats (Fig. 3). The endothelial cells of glomerular capillaries appeared weakly stained in both control and diabetic rats. The staining reaction in macula densa cells appeared to be reduced in diabetic rats compared to age-matched control rats but the reaction in both afferent and efferent arterioles remained positive in diabetic rats to similar levels seen in control rats (Fig. 3 ).

\section{Discussion}

The present study confirms the cytoplasmic localization of cNOS in macula densa cells [20-25], which are considered to regulate glomerular blood flow in response to osmotic changes in distal tubules [20, 21, 23]. The staining reaction of cNOS was well preserved by special fixation with the AMeX method which enabled the reaction products to be seen using paraffin sections, and more amenable to morphometric analysis than frozen sections. NADPH diaphorase activity was stained positive in both afferent and efferent arterioles as previously demonstrated in the mouse, rat, guinea-pig and rabbit as well as in humans [22, 24], suggesting the concurrent localization of cNOS with NADPH diaphorase in macula densa cells and the presence of endothelial type cNOS (ecNOS) or inducible type NOS (iNOS) in juxtaglomerular arterioles. The alteration of $\mathrm{cNOS}$ positive cells in macula densa cells in diabetic rats detected in the present study may further support a role for a tubuloglomerular feedback system in the functional and structural abnormalities in the pathogenesis of diabetic nephropathy [6,7].

It may be argued that the alteration of cNOS is a consequence of direct STZ toxicity or a phenomenon secondary to the severe catabolic state in STZ-induced diabetes. However, our morphometric data are comparable to those previously reported using the same model $[29,30]$, which were reversible by insulin treatment [31]. In addition, our study demonstrated that the reduction of cNOS in macula densa cells was not temporary but was consistently detected throughout the observation period, while NADPH diaphorase activity in afferent and efferent arterioles was well preserved. It has also been shown that severe diabetes in STZ-induced diabetic rats is not accompanied by renal hypertrophy [32]. These findings support the contention that the changes of cNOS are specific in diabetic rats and not the effects of STZ. Studies now underway in our laboratory on spontaneously diabetic rats may further confirm this possibility.
It is also intriguing to see whether the expression of cNOS in macula densa cells is influenced by treatment with insulin or vasoactive compounds.

At the ultrastructural level, cNOS positive reactions were present in the cell matrix not on the mitochondria, cell membrane or the nuclear elements. This is in contrast to the distribution of ecNOS, which is thought to localize in the cell membrane of endothelial cells [33]. Rasch and Holck [34, 35] demonstrated that the volume density of the lateral intercellular spaces between macula densa cells was reduced in STZ-diabetic rats but the cells showed no apparent necrosis or degeneration. In the present study, we could not demonstrate apparent degenerative or necrotic macula densa cells in diabetic rats at any time point, although there were some changes of glycogen deposition and vacuole formation in tubular cells (Ebstein-Armanni lesions). It is therefore likely that the reduced cNOS positive cells were not due to loss or destruction of macula densa cells but reflect the decreased expression of cNOS antigen in the cells. Future investigations on the cNOS mRNA expression by Northern blot analysis or in situ hybridization are important to confirm the alteration of transcript levels and to see the localization of the synthetic site for this protein.

It has been proposed that renal haemodynamics are regulated by the renin-angiotensin system and $\mathrm{NO}$ at the site of the JGA $[6,7,9,14-18]$. Inhibition of $\mathrm{NO}$ production by the NO synthase inhibitor caused rapid vasoconstriction and reduction of glomerular microcirculation [19]. NO secreted from macula densa cells is suggested to competitively function on the afferent arterioles against renin in the JGA $[20,25]$. Based on such a role for the JGA, it has been speculated that enhanced NO production is essential for early abnormalities of glomeruli in the diabetic kidney [36, 37]. Komers et al. [38] recently reported that an increase in renal plasma flow, glomerular filtration rate, and urinary $\mathrm{NO}_{2} / \mathrm{NO}_{3}$ excretion was prevented by the NO inhibitor nitro-L-arginine methyl ester in STZ-induced diabetic rats, suggesting an enhanced production of NO in the diabetic kidney. In contrast to these data, the reduced number of cNOS positive cells in macula densa cells in diabetic rats detected in the present study may argue against the hypothesis that macula densa cells are the source of increased urinary NO. NADPH diaphorase activity is known to co-localize with the site of positive reactions for neural type cNOS $[22,39]$ as well as iNOS in the kidney [23]. It is likely that afferent arterioles may be an alternative source of enhanced NO excretion in diabetic rats. A positive reaction of NADPH diaphorase in arterioles in the JGA area in diabetic rats may support this contention. Further immunohistochemical investigations using antibodies to endothelial type cNOS as well as iNOS may be necessary to elucidate the role of NO in early renal abnormalities in diabetes. 
The mechanisms of how early glomerular hyperfiltration leads to irreversible development of characteristic glomerulopathy in human diabetes are still unclear. Glomerular hyperfiltration is related to increased permeability to albumin $[36,40]$ and expansion of the filtration surface area with compensatory proliferation of mesangial cells in STZ-induced diabetic rats $[29,30,41]$. These alterations appear to be homologous to early features found in the human diabetic kidney, in which glomerular hypertrophy with mesangial expansion is claimed to be a central pathology $[42,43]$. The mesangial expansion may lead to diffuse glomerulosclerosis and increased intracapillary pressure may elicit mesangiolysis, which in turn promotes the development of nodular glomerulosclerosis $[44,45]$. It is thus possible that the haemodynamic abnormalities play a crucial role in the development of human diabetic nephropathy. Exploration of the basic mechanisms on the early abnormalities of glomerular haemodynamics is therefore of paramount importance for the prevention and treatment of the glomerular involvement in human diabetes.

Pharmacological intervention using angiotensin converting enzyme inhibitors $[46,47]$ or atrial natriuretic peptide blockers $[13,48]$ has been successful in inhibiting or preventing glomerular hyperfiltration in diabetic animal models as well as in humans. Application of aldose reductase inhibitors also significantly inhibited glomerular hyperfiltration in diabetic rats [49] and humans [50]. These findings as well as the current results suggest that the JGA functioning as a tubuloglomerular feedback system may be crucial for the development of glomerular abnormalities in diabetes.

Acknowledgements. Technical assistance by Ms. M. Sugo is greatly appreciated. This study was partly supported by a grant from the Ministry of Education, Science and Culture, Japan (\#07457055) to S. Y. and by a special grant for glycation research from Ono Pharmaceutical Co., Osaka, Japan.

\section{References}

1. Ditzel J, Schwartz M (1967) Abnormally increased glomerular filtration rate in short-term insulin-treated diabetic subjects. Diabetes 16: 264-267

2. Mogensen CE, Andersen MJF (1975) Increased kidney size and glomerular filtration rate in untreated juvenile diabetes: normalization by insulin-treatment. Diabetologia 11: 221-224

3. Christiansen JS, Gammelgaard J, Frandsen M, Parving H-H (1981) Increased kidney size, glomerular filtration rate and renal plasma flow in short-term insulin-dependent diabetics. Diabetologia 20: 451-456

4. Hostetter TH, Troy JL, Brenner BM (1981) Glomerular hemodynamics in experimental diabetes mellitus. Kidney Int 19: 410-415

5. Jensen PK, Christiansen JS, Steven K, Parving H-H (1981) Renal function in streptozotocin-diabetic rats. Diabetologia 21: 409-414
6. Brenner BM, Humes HD (1977) Mechanisms of glomerular ultrafiltration. N Engl J Med 297: 148-154

7. Hostetter TH (1992) Diabetic nephropathy. Metabolic versus hemodynamic considerations. Diabetes Care 15: 12051215

8. Wilson DM, Luetscher JA (1990) Plasma prorenin activity and complications in children with insulin dependent diabetes mellitus. N Engl J Med 323: 1101-1106

9. Correa-Rotter R, Hostetter TH, Rosenberg ME (1992) Renin and angiotensinogen gene expression in experimental diabetes mellitus. Kidney Int 41: 796-804

10. Ballermann BJ, Skorecki KL, Brenner BM (1984) Reduced glomerular angiotensin II receptor density in early untreated diabetes mellitus in the rat. Am J Physiol 247: F110-F116

11. Takagi M, Matsuoka H, Atarashi K, Yagi S (1988) Endothelin: a new inhibitor of renin release. Biochem Biophys Res Commun 157: 1164-1168

12. Ortola FV, Ballermann BJ, Anderson S, Mendez RE, Brenner BM (1987) Elevated plasma atrial natriuretic peptide levels in diabetic rats. Potential mediator of hypertension. J Clin Invest 80: 670-674

13. Kikkawa R, Haneda M, Sakamoto K et al. (1993) Antagonist for atrial natriuretic peptide receptors ameliorates glomerular hyperfiltration in diabetic rats. Biochem Biophys Res Commun 193: 700-705

14. Müller-Suur R, Ulfendahl HR, Persson AEG (1982) Evidence for the tubuloglomerular feedback in juxtamedullary nephrons in young rats. Am J Physiol 244: F425-F431

15. Casellas D, Moore LC (1990) Autoregulation and tubuloglomerular feedback in juxtamedullary glomerular arterioles. Am J Physiol 258: F660-F669

16. Skott O, Briggs JP (1987) Direct demonstration of macula densa mediated renin secretion. Science 237: 1618-1620

17. King AJ, Troy J-L, Anderson S, Neuringer JR, Gunning M, Brenner BM (1991) Nitric oxide a potential mediator of amino acid-induced renal hyperemia and hyperfiltration. J Am Soc Nephrol 1: 1271-1277

18. Tolins JP, Palmer RM, Moncada S, Raij L (1990) Role of endothelium-derived relaxing factor in regulation of renal hemodynamic responses. Am J Physiol 258: H655-H662

19. Zatz R, De Nucci G (1991) Effect of acute nitric oxide inhibition on rat glomerular microcirculation. Am J Physiol 261: F360-F363

20. Wilcox CS, Welch WJ, Murad F et al. (1992) Nitric oxide synthase in macula densa regulates glomerular capillary pressure. Proc Natl Acad Sci USA 89: 11993-11997

21. Mundel P, Backmann S, Bader M et al. (1992) Expression of nitric oxide synthase in the kidney macula densa cells. Kidney Int 42: 1017-1019

22. Schmidt HHHW, Gagne GD, Nakane M, Pollock JS, Miller MF, Murad F (1992) Mapping of neural nitric oxide synthase in the rat suggests frequent co-localization with NADPH diaphorase but not with soluble guanylyl cyclase, and novel paraneural functions for nitrinergic signal transduction. J Histochem Cytochem 40: 1439 1456

23. Tojo A, Gross SS, Zhang L et al. (1994) Immunocytochemical localization of distinct isoforms of nitric oxide synthase in the juxtaglomerular apparatus of normal rat kidney. J Am Soc Nephrol 4: 1438-1447

24. Bachmann S, Bosse H, Mundel P (1995) Topography of nitric oxide synthesis by localizing constitutive NO synthases in mammalian kidney. Am J Physiol 268: F885-F898

25. Ito S, Ren YL (1993) Evidence for the role of nitric oxide in macula densa control of glomerular hemodynamics. J Clin Invest 92: 1093-1098 
26. Sato Y, Mukai K, Watanabe S, Goto M, Shimosato Y (1986) The AMeX method. A simplified technique of tissue processing and paraffin embedding with improved preservation of antigens for immunostaining. Am $\mathrm{J}$ Pathol 125: 431-435

27. Seo HG, Tatsumi H, Fujii J et al. (1994) Nitric oxide synthase from rat colorectum: purification, peptide sequencing, partial PCR cloning, and immunohistochemistry. J Biochem 115: 602-607

28. Janssen SP, Shimouchi A, Quertermous T, Bloch DB, Bloch KD (1992) Cloning and expression of a cDNA encoding human endothelium-derived relaxing factor/nitric oxide synthase. J Biol Chem 267: 14519-14522

29. Seyer-Hansen K, Kansen J, Gundersen HJG (1980) Renal hypertrophy in experimental diabetes: a morphometric study. Diabetologia 18: 501-505

30. Kroustrup JP, Gundersen HJG, Østerby R (1977) Glomerular size and structure in diabetes mellitus. III. Early enlargement of the capillary surface. Diabetologia 13: 207210

31. Rasch R (1979) Prevention of diabetic glomerulopathy in streptozotocin diabetic rats by insulin treatment. Diabetologia 16: $125-128$

32. Seyer-Hansen K (1983) Renal hypertrophy in experimental diabetes mellitus. Kidney Int 23: 643-646

33. Moncada S, Palmer RMJ, Higgs EA (1991) Nitric oxide: physiology, pathophysiology, and pharmacology. Pharmacol Rev 43: 109-142

34. Rasch R, Holck P (1988) Ultrastructure of the macula densa in streptozotocin diabetic rats. Lab Invest 59: 666672

35. Rasch R, Holck P (1991) Macula densa morphology in diabetic rats with and without hyperglycemia and in non-diabetic hyperglycemic rats. Lab Invest 64: 392-399

36. Corbett JA, Tilton RG, Chang K et al. (1992) Aminoguanidine, a novel inhibitor of nitric oxide formation, prevents diabetic vascular dysfunction. Diabetes 41: 552-556

37. Bank N, Aynedjian HS (1993) Role of EDRF (nitric oxide) in diabetic renal hyperfiltration. Kidney Int 43: 1306-1312

38. Komers R, Allen TJ, Cooper ME (1994) Role of endothelium-derived nitric oxide in the renal hemodynamic changes of experimental diabetes. Diabetes 43: 1190-1197

39. Dawson TM, Bredt DS, Fotuhi M, Huang PM, Snyder SH (1991) Nitric oxide synthase and neuronal NADPH diaphorase are identical in brain and peripheral tissues. Proc Natl Acad Sci USA 88: 7797-7801

40. Pugliese G, Tilton RG, Speedy A et al. (1989) Effects of very mild versus overt diabetes on vascular hemodynamics and barrier function in rats. Diabetologia 32: 845-857

41. Østerby R (1988) Glomerular structural abnormalities in early and late stages of experimental diabetes: models for diabetic nephropathy? In: Shafrir E, Renold AE (eds) Frontiers in diabetes research. Lessons from animal diabetes. John Libbey \& Co. Ltd, London, pp 522-527

42. Hirose K, Tsuchida H, Østerby R, Gundersen JHG (1980) A strong correlation between glomerular filtration rate and filtration surface in diabetic kidney hyperfunction. Lab Invest 43: 434-437

43. Steffes MW, Østerby R, Chavers B, Mauer SM (1989) Mesangial expansion as a central mechanism for loss of kidney function in diabetic patients. Diabetes 38: 10771081

44. Nakamoto Y, Takazakura E, Hayakawa H et al. (1980) Intrarenal microaneurysms in diabetic nephropathy. Lab Invest 42: 433-439

45. Stout LC, Kumar S, Whorton EB (1993) Focal mesangiolysis and the pathogenesis of the Kimmelstiel-Wilson nodule. Hum Pathol 24: 77-89

46. Zatz R, Dunn R, Meyer TW et al. (1986) Prevention of diabetic glomerulopathy by pharmacological amelioration of glomerular capillary hypertension. J Clin Invest 77: 19251930

47. O'Brien RC, Cooper ME, Jerums G, Doyle AE (1993) The effects of perindopril and triple therapy in a normotensive model of diabetic nephropathy. Diabetes 42: 504-609

48. Sakamoto K, Kikkawa R, Haneda M, Shigeta Y (1995) Prevention of glomerular hyperfiltration in rats with streptozotocin-induced diabetes by an atrial natriuretic peptide receptor antagonist. Diabetologia 38: 536-542

49. Bank N, Mower P, Aynedjian HS, Wilkes BM, Silvermann $S$ (1989) Sorbinil prevents glomerular hyperperfusion in diabetic rats. Am J Physiol 256: F1000-F1006

50. Pedersen MM, Chirstiansen JS, Mogensen CE (1991) Reduction of glomerular hyperfiltration in normoalbuminuric IDDM patients by 6 mo of aldose reductase inhibition. Diabetes 40: $527-531$ 